\title{
IMPLEMENTASI SISTEM INFORMASI DATA PEMBINAAN SAPI PADA DINAS PETERNAKAN KABUPATEN TANAH LAUT
}

\section{Dwi Retnosari}

\author{
Fakultas Teknologi Informasi Universitas Islam Kalimantan (UNISKA) \\ Muhammad Arsyad Al Banjari Banjarmasin. \\ e-mail : dwiretnosarisari@gmail.com
}

Dalam rangka mendukung dan mewujudkan swasembada pangan nasional, maka pada tahun 2017 bidang produksi ternak pada Dinas peternakan Kabupaten Tanah Laut telah melaksanakan program peningkatan populasi dan produktivitas ternak, hal tersebut merupakan salah satu upaya yang dilaksanakan Dinas Peternakan Kabupaten Tanah Laut yang merupakan Lembaga Pemerintahan Provinsi Kalimantan Selatan khususnya di bidang Pembinaan hewan ternak. Proses pendataan pembinaan sapi yang dilakukan di Dinas Peternakan Kabupaten Tanah Laut saat ini dalam penyajian data dan informasi pembinaan sapi oleh peternak masih dilakukan secara manual sehingga terkadang sering terjadi kesalahan dalam proses pelaporan data dan membuat keterlambatan dalam pelayanan pendataan pembinaan sapi. Dari permasalahan yang ada maka diperlukan sebuah Implementasi Sistem Informasi Data Pembinaan Sapi Pada Dinas Peternakan Kabupaten Tanah Laut agar menghasilkan suatu sistem yang dapat mengetahui pendataan secara otomatis serta penyajian data dan informasi yang diperlukan perusahaan secara cepat dan akurat.

Metodologi yang digunakan dalam pembuatan aplikasi ini adalah metode Waterfall, dan bahasa pemrogramannya adalah bahasa pemrograman Delphi 7 dan MySQL sebagai databasenya. Dengan adanya Implementasi Sistem Informasi Data Pembinaan Sapi Pada Dinas Peternakan Kabupaten Tanah Laut maka diharapkan dapat lebih mudah dalam pendataan pembinaan sapi serta informasi yang diperlukan dapat diperoleh secara cepat dan akurat.

Kata kunci : Delphi 7, MySQL, Sistem Informasi Data Pembinaan Sapi

\section{PENDAHULUAN}

\section{Latar Belakang}

Dinas Peternakan Kabupaten Tanah

Laut yang merupakan Lembaga Pemerintahan Provinsi Kalimantan Selatan memiliki tugas di bidang Pembinaan hewan ternak khususnya dalam penyiapan pakan Jurnal Ilmiah “Technologia" ternak dan melayani kesehatan hewan dalam rangka mendukung dan mewujudkan swasembada pangan nasional. Kepala Dinas Peternakan dan Kesehatan Hewan Kabupaten Tanah Laut, Suharyo mengatakan bahwa populasi ternak sapi di Tanah Laut hingga Maret 2018 berjumlah kurang lebih 80 ribu ekor, sedangkan jumlah 
sapi Bali yang lebih dominan di ternak oleh masyarakat Tanah Laut yakni kurang lebih 50 ribu. Dari jumlah ternak sapi yang cukup banyak tersebut maka dibutuhkan suatu pengelolaan sistem pembinaan sapi yang tepat dan akurat.

Saat ini Dinas Peternakan Kabupaten Tanah Laut belum memilki sistem tentang data masyarakat veternier atau peternak hewan, Jika di amati secara langsung, pendataan yang dilakukan di dinas tersebut masih dilakukan secara manual dan tidak akurat hasil yang diperoleh. Kondisi tersebut akhirnya menghambat proses pengelolaan data yang akan dibuat, dengan demikian diperlukan suatu program untuk memudahkan dalam sistem pengelolaan pembinaan sapi. Sistem yang dibuat diharapkan dapat digunakan untuk menangani pengolahan tentang data pembinaan peternak sapi seperti data pelayanan kesehatan sapi , data masuk dan keluar sapi, data inseminasi buatan(kawin silang), data kebuntingan sapi, data perkembangan sapi serta data kematian sapi ternak. Dari sistem yang dibuat maka diharapkan dapat memudahkan pihak dinas peternakan dalam meinput data pembinaan sapi serta proses pencarian sebuah data dapat dilakukan lebih cepat dan akurat.

Jurnal Ilmiah “Technologia"
Metodologi yang digunakan dalam pembuatan sistem ini adalah metode waterfall, bahasa pemrogramannya adalah Delphi 7 dan MySQL sebagai databasenya. Dengan adanya Implementasi Sistem Informasi Data Pembinaan Sapi Pada Dinas Peternakan Kabupaten Tanah Laut maka diharapkan dapat lebih mudah dalam pendataan pembinaan sapi serta informasi yang diperlukan dapat diperoleh secara cepat dan akurat.

\section{Rumusan Masalah}

Berdasarkan latar belakang tersebut, maka rumusan masalah yang dapat dibuat pada penelitian ini yaitu "Bagaimana membuat Implementasi Sistem Informasi Data Pembinaan Sapi Pada Dinas Peternakan Kabupaten Tanah Laut".

\section{Tujuan Penelitian}

Tujuan dari penelitian ini adalah untuk membuat Implementasi Sistem Informasi Data Pembinaan Sapi Pada Dinas Peternakan Kabupaten Tanah Laut, sehingga menghasilkan sistem yang dapat mengetahui pendataan secara otomatis serta penyajian data dan informasi yang diperlukan perusahaan secara cepat dan akurat.

\section{Target Luaran}

Target Luaran yang diharapkan dengan adanya Implementasi Sistem 
Informasi Data Pembinaan Sapi Pada Dinas

Peternakan Kabupaten Tanah Laut adalah :

Publikasi ilmiah dalam jurnal Technologia

Fakultas Teknologi Informasi (UNISKA)

MAB Banjarmasin (JITFTI).

\section{METODE PENELITIAN}

Metode penelitian yang digunakan dalam pembuatan Sistem Informasi ini menggunakan metode waterfall.

Dalam metode ini dilakukan beberapa tahapan sebagai berikut :

1. Analisis Kebutuhan (Requirement Analisis)

Tahap awal dalam Analisis Kebutuhan adalah melakukan survey terhadap keinginan pemakai dan menjelaskan sistem informasi yang ideal. Artinya bahwa pengembangan sistem untuk memahami perangkat lunak yang diharapkan pengguna.

2. Sistem Desain (Design System)

Pada tahap Desain sistem menggambarkan secara singkat proses sederhana untuk pengembangan sistem dan Menentukan perangkat keras (hardware) dan perangkat lunak (software) untuk mendefinisikan arsitektur dalam Implementasi Sistem Informasi Data Pembinaan Sapi pada Jurnal Ilmiah "Technologia"
Dinas Peternakan Kabupaten Tanah Laut

3. Pelaksanaan (Implementation)

Pada tahap ini akan dijelaskan tentang bagaimana implementasi dari perancangan yang telah dibuat pada tahap sebelumnya. Bagaimana infrastruktur sistem, Bahasa pemprograman yang digunakan, serta bagaimana penggunaan database pada sistem ini.

4. Integrasi dan Pengujian Sistem (Integration and Testing)

Pada tahap ini pengembangan perangkat lunak proses unit program digabungkan dan diuji sebagai kelompok dalam berbagai cara kemudian Seluruh unit yang dikembangkan dalam tahap implementasi diintegrasikan ke dalam Sistem Informasi melalui proses pengujian Sistem

5. Operation \& Maintenance (Operasi \& Pemeliharaan)

Tahap akhir dimana suatu perangkat lunak yang sudah selesai dapat mengalami perubahan-perubahan atau penambahan sesuai dengan permintaan user. Pemeliharaan termasuk dalam memperbaiki kesalahan yang tidak ditemukan pada langkah sebelumnya. 


\section{PEMBAHASAN}

\section{Arsitektur Model Sistem}

Untuk mengatasi permasalahan yang terjadi pada sistem yang dijalankan saat ini, maka dibentuk sebuah sistem yang tentunya memiliki keunggulan, sistem tersebut digambarkan dengan diagram. Dengan diagram ini diharapkan akan mempermudah pemahaman terhadap hasil analisa, sehingga apabila terjadi kesalahan dapat diketahui sedini mungkin.

Diagram konteks merupakan tingkatan tertinggi di dalam diagram aliran data dan hanya memuat satu proses, menunjukkan sistem secara keseluruhan. Proses tersebut diberi nomor nol. Semua entitas eksternal yang ditunjukkan oleh diagram konteks berikut aliran-aliran data utama menuju dan dari sistem. Diagram tersebut tidak memuat penyimpangan data dan tampak sederhana untuk diciptakan, begitu entitas-entitas eksternal, serta aliran data-aliran data menuju dan dari sistem diketahui menganalisis dari wawancara dengan user dan sebagai hasil analisis dokumen.

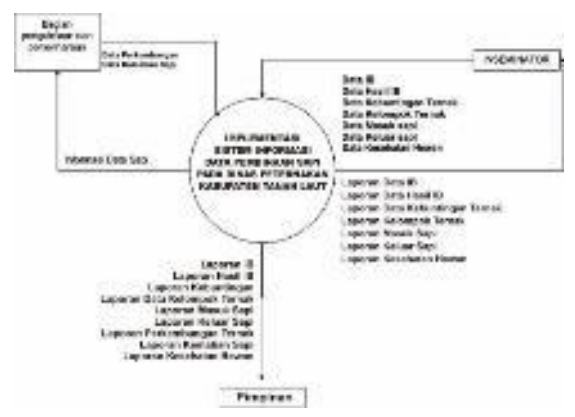

Gambar 0 Diagram Kontek

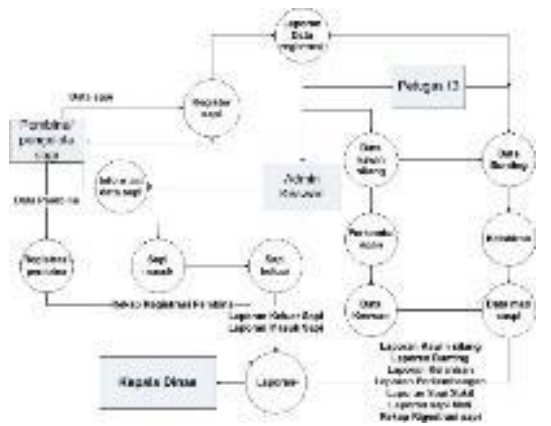

Gambar 01 Rancangan Data Flow Diagram lvl 0

Data Flow Diagram adalah suatu model logika data atau proses yang dibuat untuk menggambarkan dari mana asal data dan ke mana tujuan data yang keluar dari sistem, di mana data tersimpan, proses apa yang menghasilkan data tersebut dan interaksi antara data tersimpan dan proses yang dikenakan pada data tersebut. (Kristanto, 2008)

\section{Implementasi Sistem}

Pada implementasi sistem ini dilatampilkan semua tampilan interface seluruh halaman pada aplikasi, berikut uraiannya :

Jurnal Ilmiah "Technologia" 


\section{Form Login}

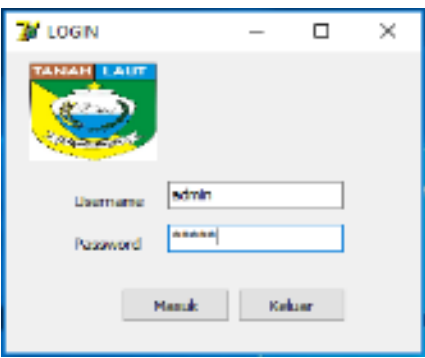

Gambar 1 F orm Login

\section{Menu Utama}

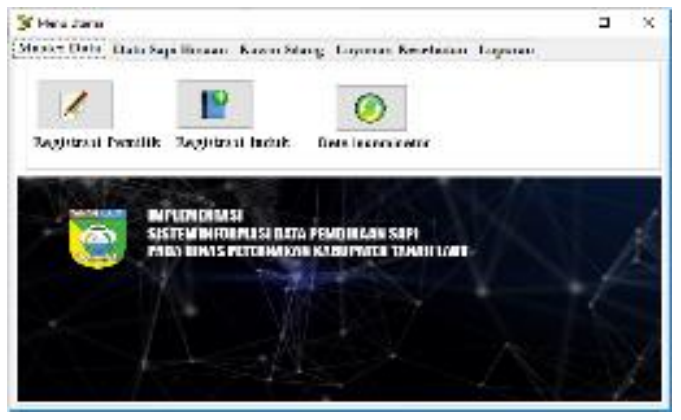

Gambar 2 Menu Utama

3. Form Input Registrasi Sapi

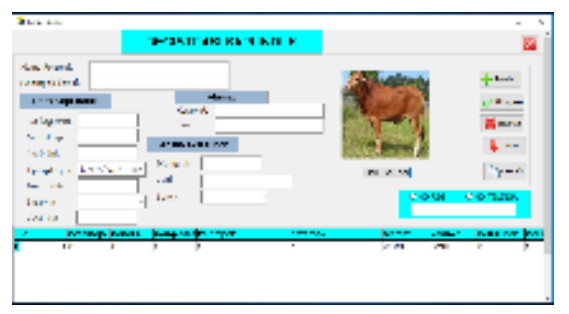

Gambar 3 Form Input Registrasi Sapi

4. Form Input Registrasi Pembina

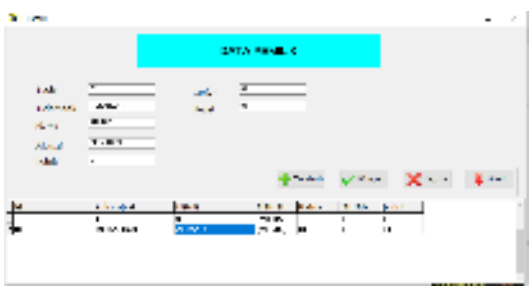

Gambar 4 Form Input Registrasi Pembina

5. Form Input Petugas Inseminator

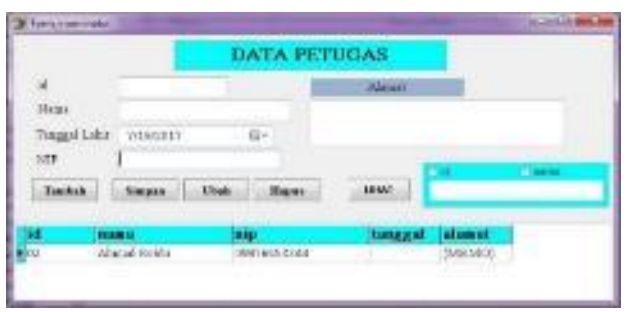

Gambar 5 Form Input Petugas Inseminator

6. Form Input Inseminasi Buatan (Kawin Silang)

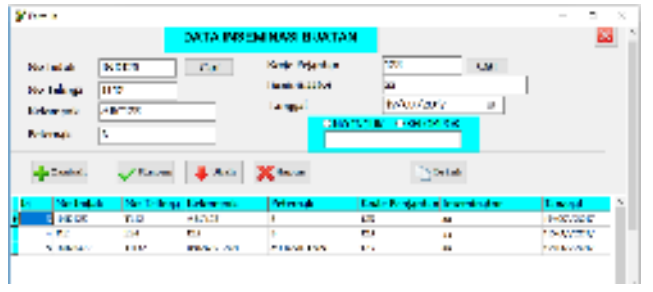

Gambar 6 Form Input Input Inseminasi Buatan (Kawin Silang)

7. Form Input Kebuntingan Sapi

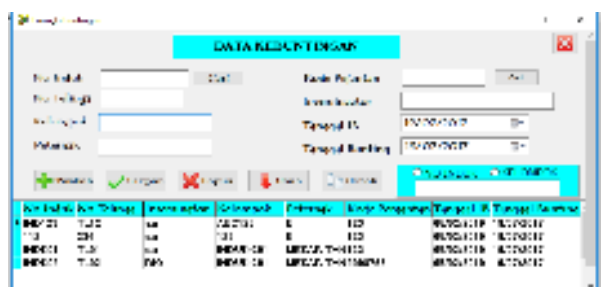

Gambar 7 Form Input Kebuntingan Sapi 
8. Form Input Kelahiran Pedet (Anak

Sapi)

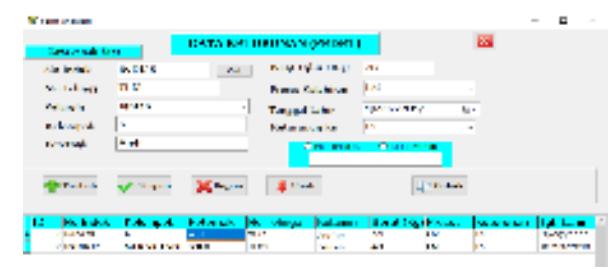

Gambar 8 Form Input Kelahiran Pedet (Anak Sapi)

9. Form Input Perkembangan

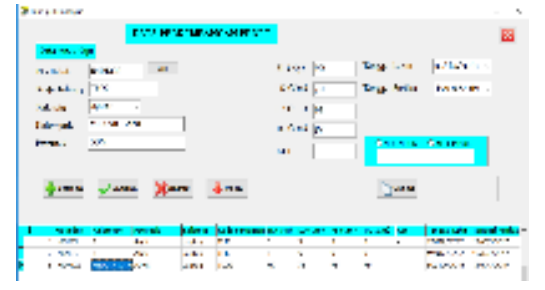

Gambar 9 Form Input Perkembangan

10. Form Input Data Keluar Sapi

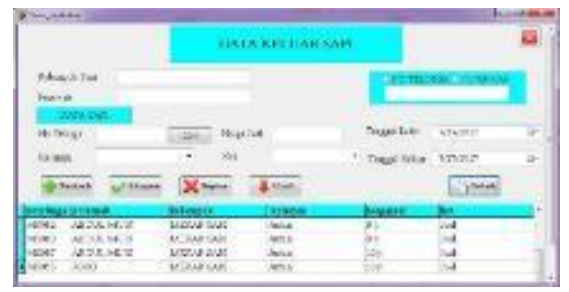

Gambar 10 Form Input Data Keluar Sapi

11. Form Input Data Masuk Sapi

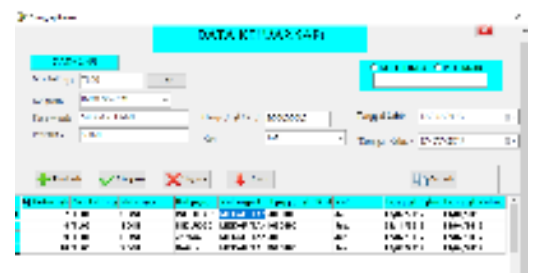

Gambar 11 Form Input Data Masuk Sapi
12. Form Input Pelayanan Kesehatan Hewan

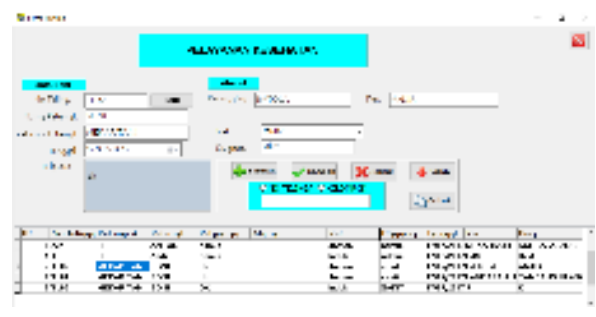

Gambar 12 Form Input Pelayanan Kesehatan Hewan

13. Form Input Kematian Sapi

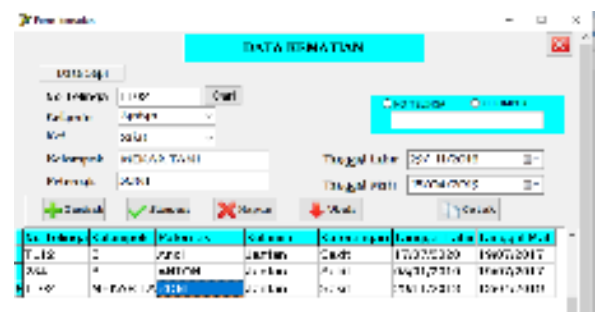

Gambar 13 Form Input Kematian Sapi

14. Laporan Inseminasi Buatan

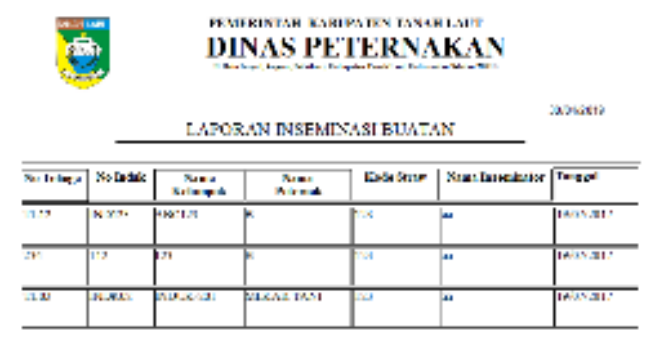

Gambar 14 Laporan Inseminasi Buatan 
15. Laporan Kelahiran Pedet ( Anak Sapi )

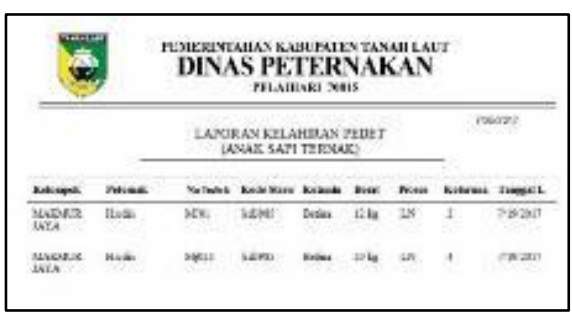

Gambar 15 Laporan Kelahiran Pedet ( Anak Sapi )

16. Laporan Perkembangan Sapi

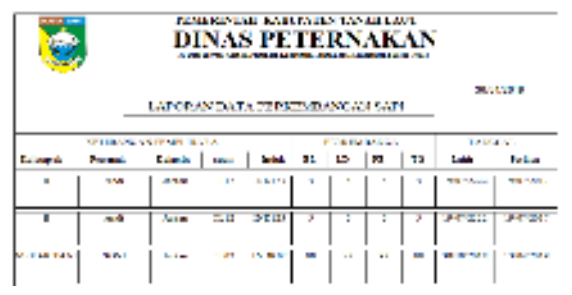

Gambar 16 Laporan Perkembangan Sapi

\section{Laporan Pelayanan Kesehatan}

(Keswan)

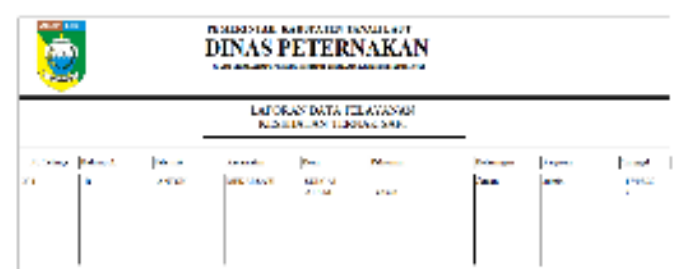

Gambar 17 Laporan Pelayanan Kesehatan (Keswan)

18. Laporan Kematian Sapi

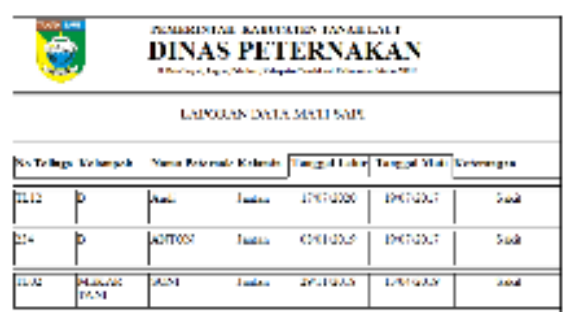

Gambar 18 Laporan Kematian Sapi
19. Laporan Masuk Sapi

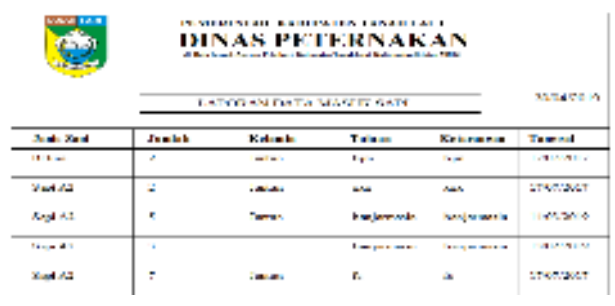

Gambar 19 Laporan Masuk Sapi

20. Laporan Keluar Sapi

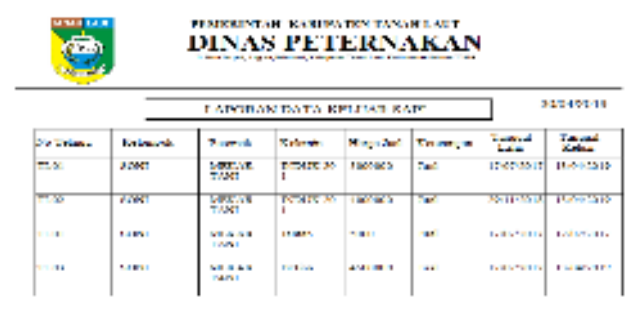

Gambar 20 Laporan Keluar Sapi

\section{KESIMPULAN}

Dengan adanya Implementasi Sistem Informasi Data Pembinaan Sapi Pada Dinas Peternakan Kabupaten Tanah Laut ini maka pihak dinas peternakan (Disnak) lebih mudah dalam pengolahan data sapi serta pencarian sebuah data lebih cepat dan akurat dalam pembinaan peternak sapi, pelayanan hewan dalam program inseminasi buatan, data kebuntingan sapi, data perkembangan sapi serta data kematian sapi ternak maupun kesehatan hewan. 


\section{DAFTAR PUSTAKA}

Abdul Kadir. (2013). Pengertian MySQL. Tersedia dalam : Buku Pintar. Yogyakarta: Mediakom.

Agus Mulyanto. (2009). Sistem Informasi Konsep dan Aplikasi. Yogyakarta: Pustaka Pelajar.

Guntur Setiawan. (2004). Implementasi Dalam Birokrasi Pembangunan . Bandung: Remaja Rosdakarya Offset.

Ichwan, M. (2011). Pemrograman basis data, delphi 7, dan mysql. Bandung: INFORMATIKA.

Jogiyanto HM. (2005). Analisis \& Desain Sistem Informasi. Yogyakarta: Pendekatan Terstruktur Teori dan Praktek Aplikasi Bisnis.

Jogiyanto.HM. (1990). Analisis \& Disain Sitem Informasi. Yogyakarta : Andi Offset.

Kani, Firmansyah, dan Sufandi, U. U. (2010). Pemrograman Database menggunakan Delphi. Jakarta: Graha Ilmu.

Kristanto, A. (2008). Data Flow Diagram. ( $2008: 61)$.

Mathis Robert, Jackson John. (2002). Manajemen Sumber Daya Manusia. Jakarta: Salemba empat.

Jurnal Ilmiah "Technologia"
McLeod, Raymond, Jr. (1996). Sistem Informasi Manajemen . Jakarta: PT. Buana Ilmu Populer.

https://kalsel.antaranews.com/berita/65611/p opulasi-sapi-tala-capai-80-ribu-ekor 